\title{
Early warning of snow-caused disasters in pastoral areas on the Tibetan Plateau
}

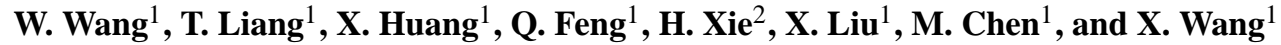 \\ ${ }^{1}$ State Key Laboratory of Grassland Agro-ecosystems; College of Pastoral Agriculture Science and Technology, \\ Lanzhou University, Lanzhou 730020, China \\ ${ }^{2}$ Department of Geological Sciences, University of Texas at San Antonio, Texas 78249, USA
}

Correspondence to: T. Liang (tgliang@1zu.edu.cn)

Received: 10 November 2012 - Published in Nat. Hazards Earth Syst. Sci. Discuss.: Revised: 20 April 2013 - Accepted: 25 April 2013 - Published: 5 June 2013

\begin{abstract}
This study develops a model for early warning of snow-caused livestock disasters on a county basis and proposes a method of qualitative risk assessment of snow disasters at $500 \mathrm{~m}$ resolution for pastoral areas on the Tibetan Plateau (TP). Data used for the model development include remote sensing data, statistical data of weather, livestock, and social economy, and 45 typical snow disaster cases from 2000 to 2010. The principal component analysis (PCA) approach is used to choose 7 crucial factors that contribute over $85 \%$ of information for early warning snow disasters on the TP. They are mean annual probability of snow disaster, number of snow-covered days, livestock stocking rate, continual days of mean daily temperature below $-10^{\circ} \mathrm{C}$, grassland burial index, rate of snow-covered grassland, and per livestock gross domestic product. The chosen 411 cases from 2008 to 2010 are used to validate the prediction results from the developed early warning model, with an overall accuracy of $85.64 \%$ in predicting snow disasters and no disasters. This suggests that the early warning approach developed in the study has operational potential for predicting snow disasters on the TP.
\end{abstract}

\section{Introduction}

Snow cover is an important part of land cover and one of the most active natural elements on the Earth surface. The dynamic change of snow cover area (SCA) has great influence on the surface albedo, climate change, hydrological circulation and energy balance, as well as social economy and ecological environment (Robock et al., 1980; Blöschl et al.,
1991; Pulliainen et al., 2006; Lemke et al., 2007; Martelloni et al., 2013). In pastoral areas, a great deal of snowfall often leads to grassland being buried and transportation disruption, resulting in a large number of deaths of livestock due to lower temperature and lack of forage stock. This has a severe influence on the sustainable development of grassland animal husbandry. In China, the natural disaster resulting in a large amount of livestock deaths by continuous snowfall in winter and spring is called snow-caused livestock disaster (Liang et al., 2007) or snow disaster in this paper. For example, in the spring of 2008 a heavy snowfall led to a snow disaster in 37 counties/cities on the Tibetan Plateau (TP), with $3.54 \times 10^{5}$ livestock deaths and 1910 million RMB losses.

Early warning and risk assessment are the two upmost important yet difficult issues in the study of snow-caused livestock disasters in pastoral areas. Early warning of snow disasters involves many factors such as grassland, snow, weather, livestock, society and economy, of which many have strong temporal and spatial heterogeneity. The accuracy of warning results is not only closely related to weather forecasting information, but also connected with regional environment conditions and capability of disaster prevention. Therefore, the premise for an operational snow disaster warning system is to (1) establish a long-term series of regional snow disaster monitoring databases and management information system using remote sensing, ground-based observation data and weather prediction data; (2) dynamically monitor the hazard-affected objects and natural environment in pastoral areas; and (3) establish snow disaster warning and risk assessment models. Furthermore, studying early warning mechanisms of snow disasters is extremely important in 
both theory and operational practice for improving the ability to prevent disaster and minimize losses in pastoral areas.

Snow disaster warning and risk assessment have been studied for a long time. Many studies have been conducted on snow cover area monitoring (Gutzler and Rosen, 1992; Hall et al., 2001; Liang et al., 2008b; Wang and Xie, 2009; Gao et al., 2010; Paudel et al., 2011), snow depth (SD) simulation (Stowe et al., 1991; Chang et al., 1996; Che et al., 2012; Frei et al., 2012; Yu et al., 2012), snow disaster risk assessment (Romanov et al., 2002), loss evaluation post-disaster (i.e., the research for the pastoral areas after snow disasters have occurred and have resulted in losses of livestock) (Nakamura and Shindo, 2001), snow disaster and avalanche mapping, as well as their relations to climate change (Jones and Jamieson, 2001; Hendrikx et al., 2005; Bocchiola et al., 2008; Delparte et al., 2008; Hirashima et al., 2008; Lato et al., 2012). In 2006, the Chinese government issued a national standard for grading snow disasters in pastoral area (GB/T 20482-2006) (General Administration of Quality Supervision of China, 2006). According to the standard, Zhou et al. (2006) analyzed the potential conditions of snow disasters based on evaluating vulnerability of hazardaffected bodies and dynamic change of precipitation in the natural environment. Liu et al. (2008) did a preliminary study on an indicating system for early warning and hazard assessment models of snow disasters in pastoral areas of northern Xinjiang, utilizing livestock mortality rate as a factor of disaster assessment. Zhang et al. (2008) proposed some indicators and methods for quantification of those indicators for early warning of snow disaster in the pastoral areas of northern Qinghai Province. Tachiiri et al. (2008) evaluated the economic loss of snow disasters in arid inland pastoral areas of Mongolia using a tree-based regression model with parameters including livestock mortality rate of current year, grassland NDVI (normalized difference vegetation index), SWE (snow water equivalent), and livestock numbers and mortality rates of previous years. In addition, Tominaga et al. (2011) predicted snow cover area and potential extent of snow disasters in built-up environments by combining a meteorological model and a computational fluid dynamics model. Nakai et al. (2012) established a snow disaster early warning system using meteorological factors (i.e., precipitation, wind speed, temperature), which would predict avalanche potential, visibility in blowing snow, and snow conditions on roads.

Snow has less impact on animal husbandry in developed countries due to better infrastructure in grassland and livestock industry, in which the studying emphasis has been particularly focused on risk assessment and early warning of traffic, landslides and avalanches related to heavy snowfall events (Jones and Jamieson, 2001; Williamson et al., 2002; Martelloni et al., 2013; Mercogliano et al., 2013; Rossi et al., 2013). As for snow disasters in pastoral areas in China, the emphasis has been placed on monitoring the change of snow distribution and livestock loss evaluation post-disasters. There has been much difficulty in snow disaster warning and risk assessments, due to lacking operational models and information system for real-time warning of snow disasters (Liang et al., 2007).

Considering the above factors and characteristics of grassland and livestock production on the TP, the purposes of this study are (1) to establish an indicator system for early warning of snow-caused livestock disasters and risk assessment based on collections of snow disasters in the past $10 \mathrm{yr}$ (2001-2010) on the TP; and (2) to establish a model for early warning and qualitative risk assessment of snow disasters and to validate the model. This study would provide a scientific basis for early warning, risk assessment, and decisionmaking of disaster prevention and relief management for the research community and local governments.

\section{Study area and data}

\subsection{Study area}

The TP $\left(26^{\circ} 00^{\prime} 12^{\prime \prime} \mathrm{N}-39^{\circ} 46^{\prime} 50^{\prime \prime} \mathrm{N}\right.$ and $73^{\circ} 18^{\prime} 52^{\prime \prime} \mathrm{E}-$ $104^{\circ} 46^{\prime} 59^{\prime \prime} \mathrm{E}$ ) is located in southwestern China. Its major part is in Qinghai and Tibet provinces, with mean elevation above $4000 \mathrm{~m}$, containing the highest pastoral areas in the world. The TP is not only the water source region of many Asian rivers such as the Yellow, Yangtze and Lantsang rivers, but also one of the three major snowfall regions in China. It consists of 201 counties that belong to Qinghai, Xinjiang, Tibet, Gansu, Sichuan and Yunnan provinces, with a total area of $2.57 \times 10^{6} \mathrm{~km}^{2}$, corresponding to $26.8 \%$ of the total areal extension of China (Fig. 1) (Zhang et al., 2002). The TP has the unique alpine meadow in the world because of its special geography, climate and natural conditions. It is an important habitat for yak, Tibetan sheep and many rare wild animals. However, because of the undeveloped agriculture infrastructure in the region, heavy snow in winter or spring often causes death of a large number of livestock due to cold weather and forage shortage. This has a great negative influence on the sustainable development of grassland animal husbandry. According to the records (Liu, 2008a; Liu, 2008b; Shi, 2008; Wang, 2008; Wen, 2008; Zhan, 2008), there have been 3228 snow disasters in this region since 1949. For example, in May of 2004, a heavy snow disaster occurred in Tongde County of Qinghai Province and caused the death of 57628 livestock; in Naqu County of the Tibetan autonomous region, snow disasters occurred in 74 months during October to May from 1971 to 2001.

\subsection{Data and sources}

\subsubsection{Statistical data}

According to the Statistical Yearbooks of China, statistic data of population, livestock (e.g., livestock number, actual livestock stocking rate), and social economy (e.g., gross 


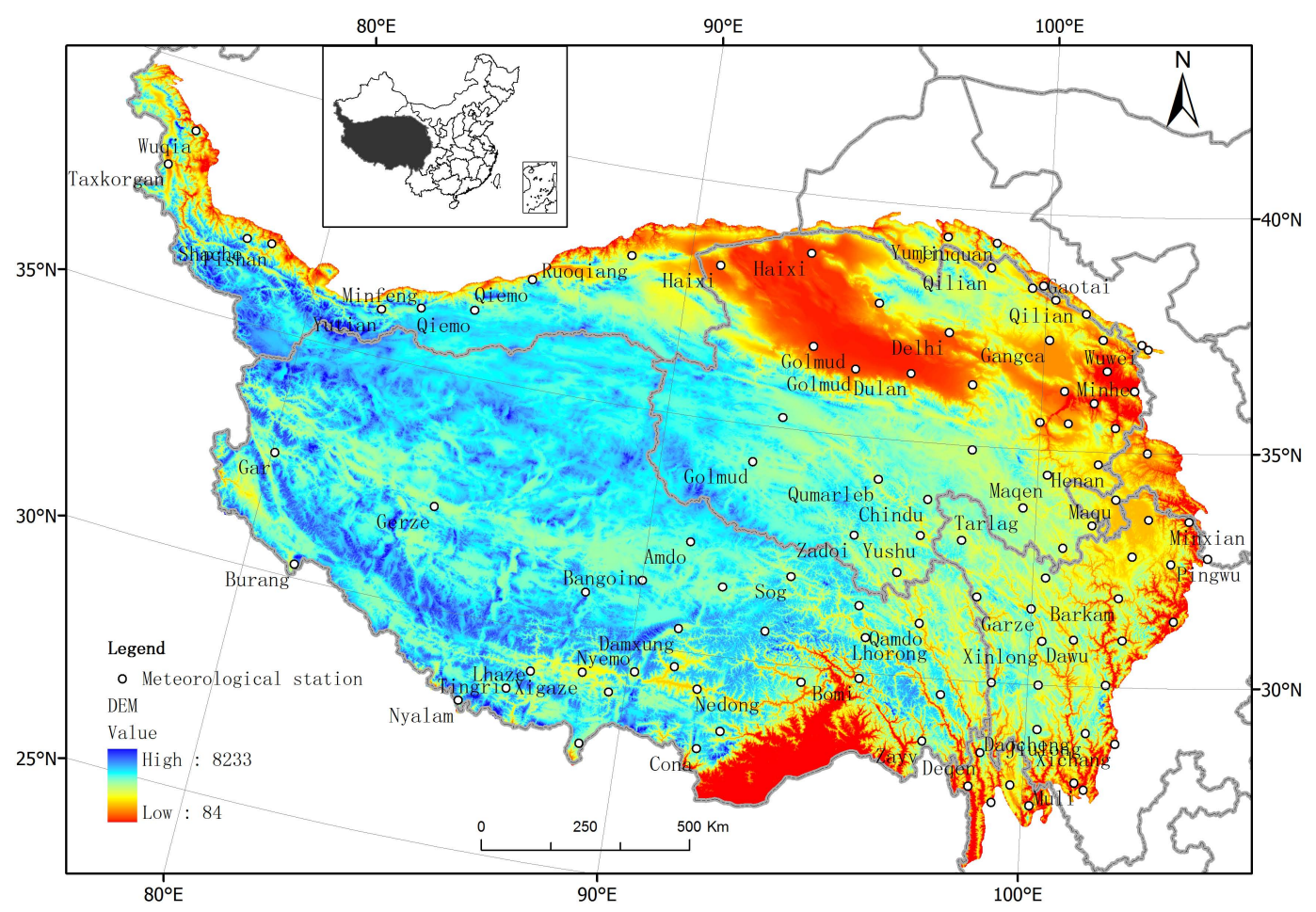

Fig. 1. Topography and distribution of meteorological stations on the TP.

domestic product: GDP) were collected for the 201 counties from 2000 to 2010.

\subsubsection{Meteorological observation data}

The daily maximum, minimum, and average temperature, precipitation, snow depth and wind speed data were collected from 106 meteorological stations of the Chinese Meteorological Data Sharing Service System (CMDS) (http: //cdc.cma.gov.cn/), for snow seasons from October to March during 2000-2010.

\subsubsection{Snow disaster probability and case data}

Based on the yearbooks of meteorological disasters from the 6 provinces on the TP (Liu, 2008a; Liu, 2008b; Shi, 2008; Wang, 2008; Wen, 2008; Zhan, 2008), we collected snow disaster data in the recent $50 \mathrm{yr}$ from 1951 to 2000 . Using county as a basic unit, we calculated the snow disaster probabilities in four time steps: monthly, winter (i.e., from September to February of the next year), spring (i.e., from March to May), and mean annual. In particular, 45 typical snow disaster cases (33 in Qinghai and 12 in Tibet) from 2001 to 2010 (Table 1), which were representatives in spatial distribution, occurrence time, and harmful level of snow disasters on the TP, were selected for detailed analysis and model building. The basic requirements that a typical case of snow disaster must meet are (1) specific records of start time, end time and number of livestock loss on a county basis; (2) complete weather, grassland and livestock statistics; and (3) availability of remotely sensed snow cover area, snow depth and snow-covered days on grassland.

We also selected 411 cases, 243 cases of snow disaster and 168 cases of no snow disaster, from 2008 to 2010 for validation of the early warning model of snow disasters. These cases came from 158 counties (out of the total 201 counties) in the study area and were representative for the validation purpose. The major difference between those 45 cases for model building and 411 cases for model validation is that the later cases (1) only have records on whether there was snow disaster or no disaster and (2) have no detailed numbers of livestock death for those snow disaster cases.

\subsubsection{DEM, grassland type and height data}

The Shuttle Radar Topography Mission (SRTM) $90 \mathrm{~m}$ digital elevation model (DEM) data were downloaded from the CGIAR Consortium for Spatial Information (CGIARCSI) (http://srtm.csi.cgiar.org). Grassland type data were from China Grassland Resources (Ministry of Agriculture of the People's Republic of China, Animal Husbandry Department, 1986) and were used to build an average grass height database for different grassland types based on ground truth data of each grassland vegetation type obtained during 20052006 on the TP (Feng et al., 2011). 
Table 1. Typical cases of snow disaster on the TP.

\begin{tabular}{|c|c|c|c|c|}
\hline Year & Disaster month & Time & Place & Snow disaster level \\
\hline 2001 & $\begin{array}{l}\text { March, May in Tibet } \\
\text { and April in Qinghai }\end{array}$ & 3 & $\begin{array}{l}\text { Tongde County in Qinghai, Cuona and } \\
\text { Gaize counties in Tibet }\end{array}$ & Light disaster (3) \\
\hline 2002 & $\begin{array}{l}\text { January in Tibet and } \\
\text { March in Qinghai }\end{array}$ & 2 & $\begin{array}{l}\text { Lang County in Tibet, Tongde } \\
\text { County in Qinghai }\end{array}$ & Light disaster (2) \\
\hline 2003 & February in Tibet & 1 & Nie lamu County in Tibet & Light disaster (1) \\
\hline 2004 & $\begin{array}{l}\text { February, October in Tibet and } \\
\text { January, May in Qinghai }\end{array}$ & 12 & $\begin{array}{l}\text { Cuona County and Suo County in Ti- } \\
\text { bet, Wulan, Dulan, Delingha, Tianjun, } \\
\text { Zeku, Henan Mongolian Autonomous } \\
\text { County, Delingha, Tongde, Xunhua } \\
\text { Salar Autonomous County in Qinghai }\end{array}$ & $\begin{array}{l}\text { Light disaster }(10) \text {, } \\
\text { moderate disaster } \\
(2)\end{array}$ \\
\hline 2005 & $\begin{array}{l}\text { February, March, May } \\
\text { in Qinghai }\end{array}$ & 16 & $\begin{array}{l}\text { Dari, Banma, Xinghai, Zuku, Gonghe, } \\
\text { Gangcha, Huangyuan, Datong Hui Na- } \\
\text { tionality Autonomous County, Yushu, } \\
\text { Chenduo, Qumalai, Tongde, Tongren, } \\
\text { Tianjun County in Qinghai }\end{array}$ & Light disaster (16) \\
\hline 2006 & $\begin{array}{l}\text { March, April in Tibet and } \\
\text { February, April in Qinghai }\end{array}$ & 5 & $\begin{array}{l}\text { Nie mula County, Gaize County in Ti- } \\
\text { bet, Dulan County, Tongren County in } \\
\text { Qinghai }\end{array}$ & $\begin{array}{l}\text { Light disaster (4), } \\
\text { extremely severe } \\
\text { disaster (1) }\end{array}$ \\
\hline 2007 & March in Qinghai & 2 & $\begin{array}{l}\text { Xunhua Salar Autonomous County and } \\
\text { De Lingha County in Qinghai }\end{array}$ & Light disaster (2) \\
\hline 2008 & January, October in Tibet & 3 & $\begin{array}{l}\text { Angren County, Chayu County, Jiali } \\
\text { County in Tibet }\end{array}$ & Light disaster (3) \\
\hline 2009 & May in Tibet & 1 & Angren County in Tibet & Light disaster (1) \\
\hline
\end{tabular}

\subsubsection{Snow remote sensing monitoring data}

In this study, remotely sensed snow cover and snow depth data are used. The Advanced Microwave Scanning Radiometer-Earth Observing System (AMSR-E) supplied SWE and brightness temperature (BT) products (Che et al., 2012; Frei et al., 2012). Previous research has shown that AMSR-E BT data can simulate snow depth of the Heihe River watershed and Xinjiang region in China with accuracy above $78 \%$ (Che et al., 2004, 2012; Dai et al., 2012). Using AMSR-E BT data and state-of-the-art simulation methods (Foster et al., 1997; Yu et al., 2012), we have built a snow depth model on the TP, and have produced SD images daily, every 5 days and every 10 days from 2001 to 2010.

Moderate-Resolution Imaging Spectroradiometer (MODIS) snow cover products have been used in snow monitoring, snowmelt runoff modeling and data assimilation (Hall et al., 2002; Rodell and Houser, 2004; Gao et al., 2010). Based on daily MODIS and AMSR-E SWE data in snow seasons (October-March) from 2001 to 2010, daily, 5-day, and 10-day combinations of MODIS and AMSR-E snow cover area databases have been established for the TP (Liang et al., 2008a; Wang and Xie, 2009; Yu et al., 2012) and are used in this study.

\section{Factors of snow disaster early warning and risk assessment}

Snow disaster warning and risk assessment mainly involve factors such as terrain, grassland, snow, weather, livestock, and social economy and are detailed below.

1. Terrain and grassland factors. These factors mainly include (1) the topography conditions (e.g., slope, aspect) and grassland distribution; and (2) herbage growing status (e.g., herbage yield, cover and height of different grassland types).

2. Snow and weather factors. They mainly include (1) snow disaster probability based on data of $50 \mathrm{yr}$ (1951-2000) on a county basis; (2) grassland snow depth and number of snow-covered days, the rate of snow-covered county area, the rate of snowcovered grassland area, grassland burial index (i.e., the ratio of snow depth to grass height) in the county; and (3) meteorological conditions during a snow-covered period (e.g., daily minimum, maximum, and average temperatures, precipitation, and snow depth observed at the 106 climatic stations) and continuous days of low 
Table 2. Results of linear correlations between the number of livestock deathd and the 20 indicators.

\begin{tabular}{|c|c|c|c|}
\hline Variable code & Variable name & $\begin{array}{l}\text { Linear relation and } \\
\text { correlation coefficient } \\
(|\mathrm{R}|)\end{array}$ & Description \\
\hline a1 & $\begin{array}{l}\text { Continued days of } \\
\text { snow disaster }\end{array}$ & +0.27 & $\begin{array}{l}\text { In a period from the start date of a warning period to the end } \\
\text { date of the same period in one snow season. }\end{array}$ \\
\hline $\mathrm{a} 2$ & $\begin{array}{l}\text { Gross regional domes- } \\
\text { tic product }(\mathrm{GDP})\end{array}$ & -0.58 & The unit is RMB (Chinese Yuan). \\
\hline a3 (X1) & Per capita GDP & -0.65 & The unit is RMB (Chinese Yuan). \\
\hline a4 (X2) & Herbage yield & +0.60 & The unit is kilograms per hectare $\left(\mathrm{kg} \mathrm{ha}^{-1}\right)$. \\
\hline a5 (X3) & $\begin{array}{l}\text { Probability of spring } \\
\text { snow disaster }\end{array}$ & +0.74 & $\begin{array}{l}\text { According to the yearbooks of meteorological disasters from } \\
1951 \text { to } 2000 \text {. }\end{array}$ \\
\hline a6 (X4/a) & $\begin{array}{l}\text { Mean annual } \\
\text { probability } \\
\text { of snow disaster }\end{array}$ & +0.79 & $\begin{array}{l}\text { According to the yearbooks of meteorological disasters from } \\
1951 \text { to } 2000 \text {. }\end{array}$ \\
\hline a7 & $\begin{array}{l}\text { Rate of snow-covered } \\
\text { grassland }\end{array}$ & +0.56 & $\begin{array}{l}\text { (i) Ratio of snow cover area to grassland area on a county basis } \\
\text { (ii) Calculated in a period from the start date of a warning period } \\
\text { to the end date of the same period in one snow season. }\end{array}$ \\
\hline $\mathrm{a} 8\left(\mathrm{X} 5 / \mathrm{c}_{1}\right)$ & $\begin{array}{l}\text { Rate of snow-covered } \\
\text { grassland }\end{array}$ & +0.67 & $\begin{array}{l}\text { (i) Ratio of snow cover area to grassland area on a county basis } \\
\text { (ii) Calculated in a period from } 20 \text { days before the start date of } \\
\text { a warning period to the end date of the same warning period in } \\
\text { one snow season. }\end{array}$ \\
\hline a9 & $\begin{array}{l}\text { Number of snow- } \\
\text { covered days }\end{array}$ & +0.22 & $\begin{array}{l}\text { (i) From remote sensing } \\
\text { ii) Calculated in a period from the start date of a warning period } \\
\text { to the end date of the same period in one snow season. }\end{array}$ \\
\hline a10 $\left(\mathrm{X} 6 / \mathrm{c}_{2}\right)$ & $\begin{array}{l}\text { Number of snow- } \\
\text { covered days }\end{array}$ & +0.66 & $\begin{array}{l}\text { (i) From remote sensing } \\
\text { ii) Calculated in a period from } 20 \text { days before the start date of } \\
\text { a warning period to the end date of the same warning period in } \\
\text { one snow season. }\end{array}$ \\
\hline a11 & $\begin{array}{l}\text { Mean daily temperature } \\
\text { below } 0{ }^{\circ} \mathrm{C}\end{array}$ & +0.34 & $\begin{array}{l}\text { (i) From meteorological stations } \\
\text { (ii) Calculated in a period from the start date of a warning period } \\
\text { to the end date of the same period in one snow season. }\end{array}$ \\
\hline a12 (X7) & $\begin{array}{l}\text { Mean daily temperature } \\
\text { below } 0^{\circ} \mathrm{C}\end{array}$ & +0.61 & $\begin{array}{l}\text { (i) From meteorological stations } \\
\text { (ii) Calculated in a period from } 20 \text { days before the start date of } \\
\text { a warning period to the end date of the same warning period in } \\
\text { one snow season. }\end{array}$ \\
\hline a13 & $\begin{array}{l}\text { Continual days of mean } \\
\text { daily temperature be- } \\
\text { low }-10^{\circ} \mathrm{C}\end{array}$ & +0.54 & $\begin{array}{l}\text { (i) From meteorological stations } \\
\text { (ii) Calculated in a period from the start date of a warning period } \\
\text { to the end date of the same period in one snow season. }\end{array}$ \\
\hline a14 (X8/b) & $\begin{array}{l}\text { Continual days of mean } \\
\text { daily temperature be- } \\
\text { low }-10^{\circ} \mathrm{C}\end{array}$ & +0.70 & $\begin{array}{l}\text { (i) From meteorological stations } \\
\text { ii) Calculated in a period from } 20 \text { days before the start date of } \\
\text { a warning period to the end date of the same warning period in } \\
\text { one snow season. }\end{array}$ \\
\hline a15 & $\begin{array}{l}\text { Continual days of mean } \\
\text { daily temperature be- } \\
\text { low }-20^{\circ} \mathrm{C}\end{array}$ & +0.52 & $\begin{array}{l}\text { (i) From meteorological stations } \\
\text { (ii) Calculated in a period from the start date of a warning period } \\
\text { to the end date of the same period in one snow season. }\end{array}$ \\
\hline a16 & $\begin{array}{l}\text { Continual days of mean } \\
\text { daily temperature be- } \\
\text { low }-20^{\circ} \mathrm{C}\end{array}$ & +0.58 & $\begin{array}{l}\text { (i) From meteorological stations } \\
\text { (ii) Calculated in a period from } 20 \text { days before the start date of } \\
\text { a warning period to the end date of the same warning period in } \\
\text { one snow season. }\end{array}$ \\
\hline a17 & Minimum temperature & +0.35 & From meteorological stations \\
\hline a18 $\left(X 9 / c_{3}\right)$ & Grassland burial index & +0.65 & Ratio of snow depth to grassland height \\
\hline a19 (X10) & Livestock stocking rate & +0.64 & Ratio of number of sheep unit to grassland area (su/ha) \\
\hline a20 (X11/d) & Per livestock GDP & -0.71 & Ratio of per capita GDP to livestock number (Yuan/su) \\
\hline
\end{tabular}


Table 3. Correlation matrix of PC components.

\begin{tabular}{llllllllllll}
\hline Factor & $\mathrm{X} 3$ & $\mathrm{X} 5$ & $\mathrm{X} 6$ & $\mathrm{X} 7$ & $\mathrm{X} 8$ & $\mathrm{X} 9$ & $\mathrm{X} 10$ & $\mathrm{X} 2$ & $\mathrm{X} 1$ & $\mathrm{X} 11$ & $\mathrm{X} 4$ \\
\hline $\mathrm{X} 3$ & 1.000 & & & & & & & & & & \\
$\mathrm{X} 5$ & .254 & 1.000 & & & & & & & & & \\
$\mathrm{X} 6$ & -.014 & .178 & 1.000 & & & & & & & & \\
$\mathrm{X} 7$ & .166 & .295 & .731 & 1.000 & & & & & & & \\
$\mathrm{X} 8$ & .240 & .137 & .284 & .635 & 1.000 & & & & & & \\
$\mathrm{X} 9$ & .201 & .253 & .165 & .042 & .171 & 1.000 & & & & & \\
$\mathrm{X} 10$ & -.137 & -.151 & .050 & .038 & -.044 & -.156 & 1.000 & & & & \\
$\mathrm{X} 2$ & .070 & .040 & -.338 & -.237 & -.001 & .027 & -.397 & 1.000 & & & \\
$\mathrm{X} 1$ & .034 & -.033 & .342 & .358 & .068 & .151 & -.123 & .017 & 1.000 & & \\
$\mathrm{X} 11$ & -.314 & -.222 & .142 & .031 & -.139 & -.175 & .222 & -.164 & .046 & 1.000 & \\
$\mathrm{X} 4$ & .813 & .279 & -.115 & .001 & .001 & .326 & -.304 & .184 & .076 & -.355 & 1.000 \\
\hline
\end{tabular}

temperature (i.e., below $0{ }^{\circ} \mathrm{C}$, below $-10^{\circ} \mathrm{C}$, or below $\left.-20^{\circ} \mathrm{C}\right)$.

3. Livestock factors. Livestock is the main hazard-affected body. The related factors mainly include number of livestock at the beginning of a year, number of livestock by end of a year, actual livestock stocking rate, and fraction of small livestock.

4. Social economy factors. These factors mainly include (1) social and economic factors consisting of population, per capita gross domestic product (GDP), per capita farming income, density of road network, and spatial distribution of residential areas; (2) forage stock and shed rate of livestock; and (3) per livestock GDP (i.e., the ratio of regional GDP to the number of livestock by the end of a year).

\section{Model development for early warning and qualitative risk assessment of snow disasters}

Early warning of snow disaster requires developing a model that can be used to quantify the potential damages caused by heavy snowfall events in a particular period and area. In this study, we use the chosen 45 typical cases of snow disasters in recent $10 \mathrm{yr}$ to build a database of 20 indicators (see Tables 1 and 2), which relate to terrain and grassland, snow and weather, livestock, and social economy. From the known 20 indicators, we first select those indicators that show good correlation with the livestock death (Nagelkerke, 1991; Freedman et al., 1998). Second, using the principal component analysis (PCA) method (Lu et al., 1997), a few key factors used for early warning of snow disasters are then determined. Third, based on the relation between the determined key factors and the death numbers of livestock of the 45 cases, an early warning model on a county basis is then established using a multivariate nonlinear regression method. Finally, we establish a lookup table for qualitative risk assessment of snow disasters with a grid cell size of $500 \mathrm{~m} \times 500 \mathrm{~m}$.

\subsection{The statistic analysis of crucial factors}

As shown in Table 2, of the 20 indicators, 11 indicators show significant correlations with livestock death $(-R-\geq 0.60)$, 2 negative and 9 positive correlations. The 2 negative indicators are per capita GDP (a3) and per livestock GDP (a20). The 9 positive indicators are herbage yield (a4), probability of spring snow disaster (a5), mean annual probability of snow disaster (a6), rate of snow-covered grassland (a8), number of snow-covered days (a10), mean daily temperature below $0{ }^{\circ} \mathrm{C}(\mathrm{a} 12)$, continual days of mean daily temperature below $-10^{\circ} \mathrm{C}(\mathrm{a} 14)$, grassland burial index (a18), and livestock stocking rate (a19). Therefore, we used these 11 indicators to analyze key factors for early warning of snow disasters on the TP.

To remove potential redundant information from the 11 indicators, we use the PCA method to further examine them. The PCA result (Table 3) shows that there are high positive correlations between probability of spring snow disaster (X3) and mean annual probability of snow disaster (X4), between days of mean daily temperature below $0^{\circ} \mathrm{C}(\mathrm{X} 7)$ and number of snow-covered days (X6), and between days of mean daily temperature below $0{ }^{\circ} \mathrm{C}(\mathrm{X} 7)$ and continuous days of mean daily temperature below $-10^{\circ} \mathrm{C}(\mathrm{X} 8)$. The correlation coefficients are $0.813,0.731$ and 0.635 , respectively. This suggests that those variables are closely related and have redundant information to some extent. However, the coefficient between mean annual probability of snow disaster (X4) and per livestock GDP (X11) is negative $(-0.355)$, which means per livestock GDP represents the comprehensive capability of disaster resistance.

Table 4 shows that the first $7 \mathrm{PC}$ components have reached $85 \%$ of cumulative contribution from 11 variables. The contributions from each of the 11 variables to the $7 \mathrm{PC}$ components are shown in Table 5. In general the variable with the highest loadings can be treated as the representative of the PC component (Lu et al., 1997). Therefore, we choose X4, $\mathrm{X} 6, \mathrm{X} 10, \mathrm{X} 8, \mathrm{X} 9, \mathrm{X} 5$, and $\mathrm{X} 11$, respectively, as the PC components $1,2,3,4,5,6$, and 7 . 


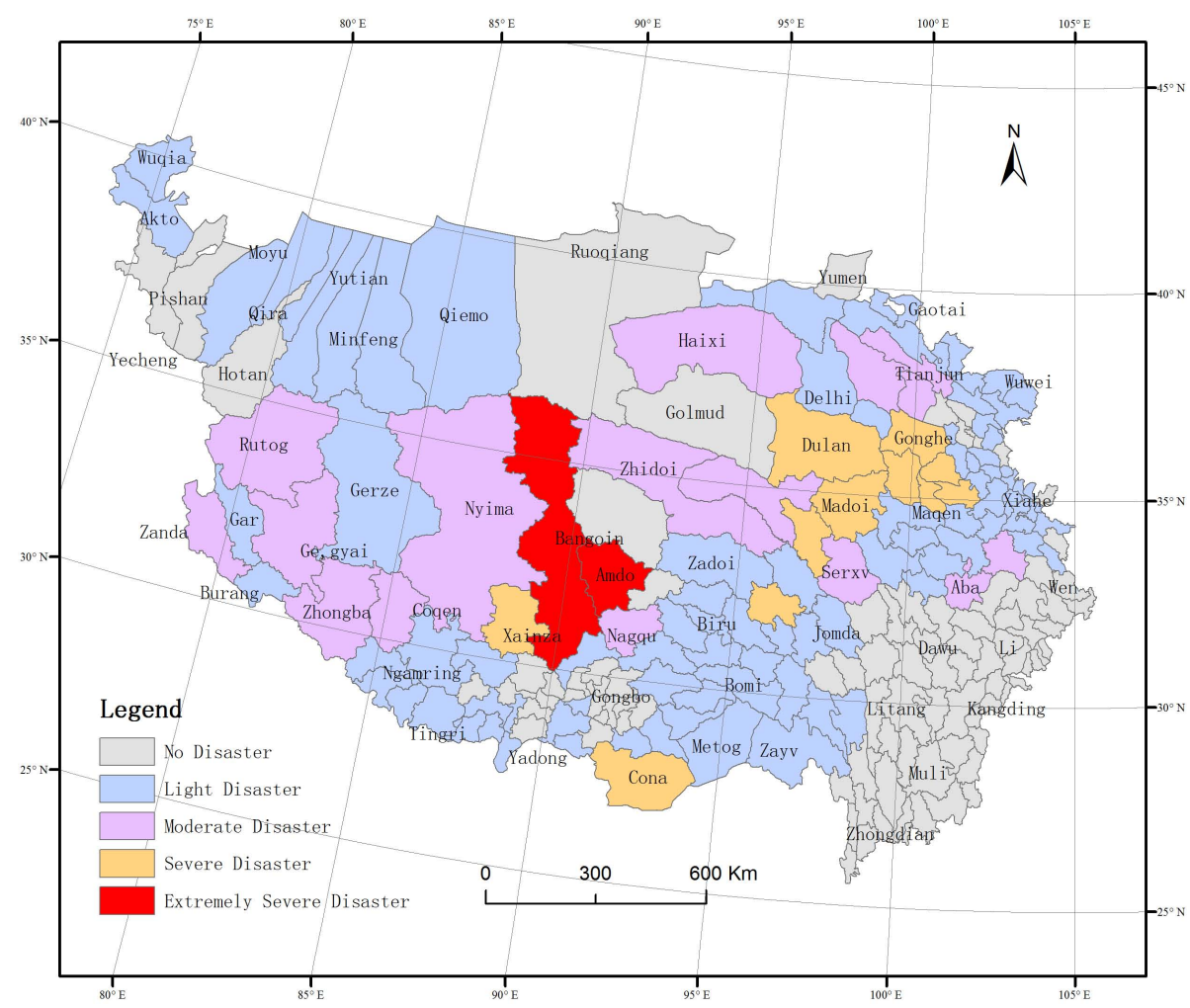

Fig. 2. Snow disaster warning simulation result (county basis) of the TP in late January $2008(\mathrm{~J}=12)$.

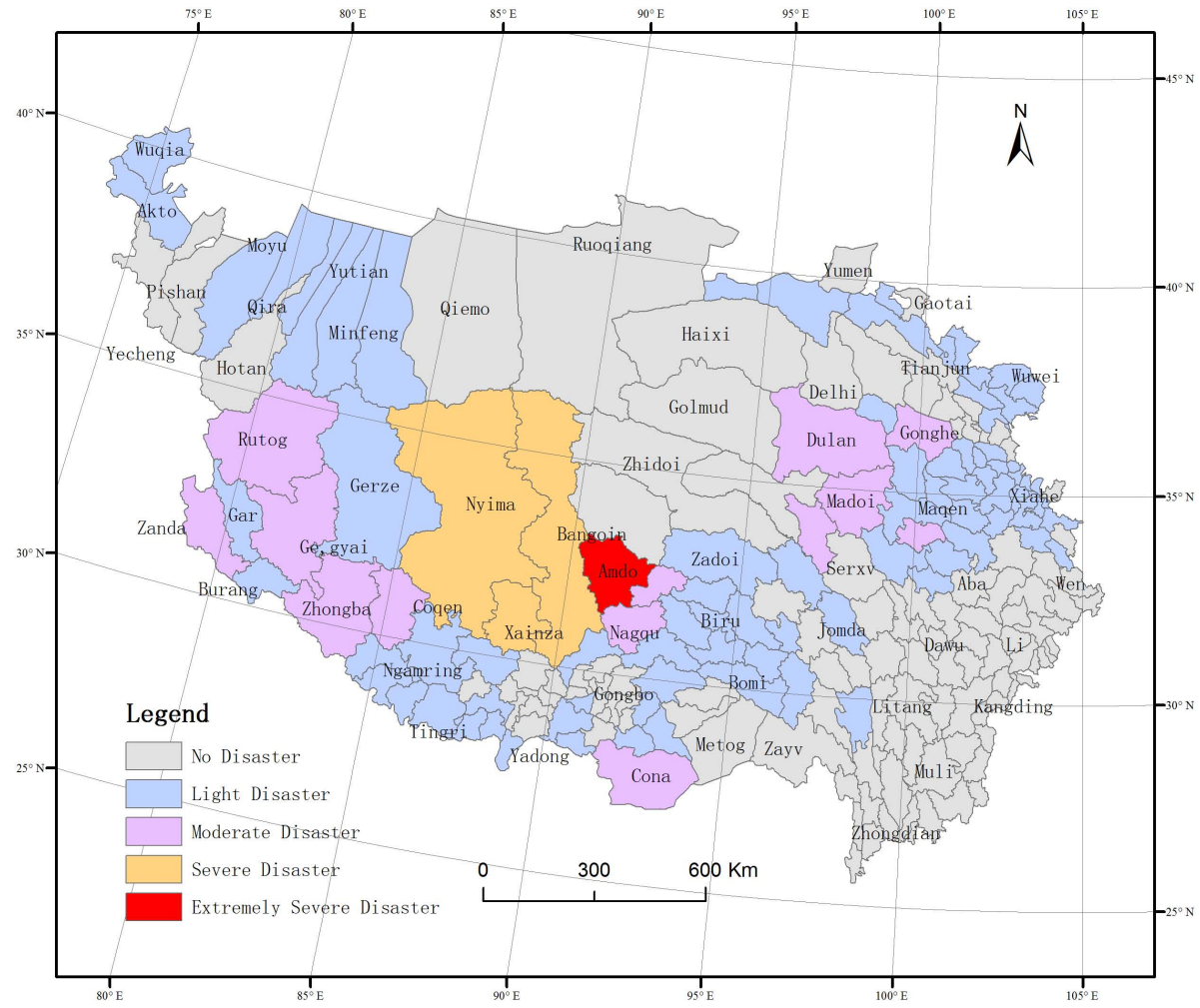

Fig. 3. Snow disaster warning simulation result (county basis) of the TP in early February $2008(\mathrm{~J}=13)$ 
Table 4. Total variance explained by each PC component.

\begin{tabular}{llll}
\hline \multirow{2}{*}{ Component } & \multicolumn{3}{c}{ Initial eigenvalue } \\
\cline { 2 - 4 } & Total & \% of variance & Cumulative \% \\
\hline 1 & 2.665 & 24.226 & 24.226 \\
2 & 2.232 & 20.291 & 44.517 \\
3 & 1.220 & 11.088 & 55.605 \\
4 & 1.009 & 9.170 & 64.775 \\
5 & .921 & 8.370 & 73.145 \\
6 & .811 & 7.369 & 80.514 \\
7 & .709 & 6.446 & 86.961 \\
8 & .594 & 5.403 & 92.364 \\
9 & .407 & 3.704 & 96.067 \\
10 & .313 & 2.847 & 98.914 \\
11 & .119 & 1.086 & 100.000 \\
\hline
\end{tabular}

\subsection{Construction of the early warning model of snow disaster grades}

Using the seven key factors as independent variables and the number of livestock death from snow disasters as the dependent variable, multivariate nonlinear regression simulation is performed based on the 45 cases of snow disaster data, and the final regression Eq. (1) is then achieved:

$Z_{i j}=\frac{57.850 \times a_{i j}+64.891 \times b_{i j}+8496 \times \prod_{\mathrm{k}=1}^{\mathrm{n}}\left(c_{\mathrm{k}, \mathrm{ij}}\right)}{d_{i j}}$,

where $Z_{i j}$ is number of livestock deaths on a county basis for a warning period; $i$ is the number of counties $(i=1,2$, $3, \ldots, n$, and $n=201) ; j$ is the number of warning periods ( $j=1,2,3, \ldots, m$, and $m=18$, total warning periods in each snow season from 1 October to 31 March (10 days per warning period); for example, warning period 1 or 2 (i.e., $j=1$ or 2) is from 1 October to 10 October or from 11 October to 20 October); $a$ is mean annual probability of snow disaster (X4); $b$ is continuous days of mean daily temperature below $-10^{\circ} \mathrm{C}(\mathrm{X} 8) ; c_{k}$ (where $k=1$ to 4 ) are respectively the rate of snow-covered grassland (X5), number of snowcovered days (X6), grassland burial index (X9), and livestock stocking rate (X10); and $d$ is per livestock GDP (X11).

Referring to the national standard "grades of snow disaster in pastoral area" (General Administration of Quality Supervision of China, 2006), in this study we classify the snow disaster (here referring to $Z_{i j}$ ) into five grades: no disaster, light disaster, moderate disaster, severe disaster and extremely severe disaster (Table 6).

Using the above-derived model and grade standard, we conduct simulations of snow disasters in recent $3 \mathrm{yr}(2008$ 2010) and perform detailed analysis. Figures 2 and 3 are two examples showing the early warning results with 5 grades of snow disasters for the periods $(\mathrm{J}=12,13)$ in the 2008 snow season. Fig. 2 shows that extremely severe disaster events could have occurred in both Bangoin and Amdo counties in the central TP, severe disaster events in 11 counties mainly in the northeastern TP, moderate disaster events in 15 counties comprising a northeast to southwest strip, and light disaster and no disaster events mainly outside of the strip. Figure 3 shows that only Amdo County could have remained the same grade of extremely severe disaster, Xainza County remained the same grade of severe disaster, while Bangoin County downgraded from extremely severe disaster to severe disaster, and Nyima County upgraded from moderate disaster to severe disaster; moderate and light disaster events reduced a lot; many more counties changed to no disaster and were mainly in the eastern and central-northern TP. The above early warning results are found in good agreement with real situations recorded or reported in that time period (China Meteorological Administration, 2011).

Based on the simulation results of the $3 \mathrm{yr}$, we obtain the following experiences and suggestions for future applications using the snow warning model.

1. The exact time periods for each variable are defined as follows: a (the mean annual probability of snow disaster) is for the previous $50 \mathrm{yr}(1951-2000)$ and is a constant now in Eq. (1); b (continual days of mean daily temperature below $-10^{\circ} \mathrm{C}$ ), $\mathrm{c}_{1}$ (rate of snow-covered grassland), $c_{2}$ (number of snow-covered days), and $c_{3}$ (grassland burial index) are all from 20 days before the start date of a warning period to the end date of the same warning period in one snow season; and $\mathrm{c}_{4}$ (livestock stocking rate) and d (per livestock GDP) are data all from the previous calendar year of a warning period.

2. Rate of snow-covered grassland $\left(c_{1}\right)$ and number of snow-covered days $\left(c_{2}\right)$ are statistical data on a county basis based on remote sensing data (e.g., 10-day composites of MODIS and AMSR-E products) or observed data from climate stations.

3. Snow depth used for deriving grassland burial index $\left(c_{3}\right)$ can be calculated from remote sensing data (e.g., daily MODIS and AMSR-E composite data for this study); and it is the maximum snow depth from 20 days before the start date of a warning period to the end date of the same warning period in one snow season.

4. The county is marked as "no disaster" when both the rate of snow-covered grassland $\left(\mathrm{c}_{1}\right)$ satisfies $0<\mathrm{c} 1<30 \%$ and grassland burial index $\left(\mathrm{c}_{3}\right)$ satisfies $0<\mathrm{c} 3<35 \%$.

\subsection{Qualitative risk assessment of snow disasters}

The above-derived maps of snow disaster grades (such as Figs. 2 and 3) are on a county basis and cannot tell the detailed risk distribution and variability within a county. We thus propose a method to produce potential risk intensity 
Table 5. Factor loading matrix showing contribution of each factor to all PC components.

\begin{tabular}{|c|c|c|c|c|c|c|c|c|}
\hline \multirow[t]{2}{*}{ Factor name } & \multirow[t]{2}{*}{ Factor code } & \multicolumn{7}{|c|}{ PC component } \\
\hline & & 1 & 2 & 3 & 4 & 5 & 6 & 7 \\
\hline Probability of spring snow disaster & $\mathrm{X} 3$ & .770 & -.137 & -.365 & .233 & .344 & -.024 & .158 \\
\hline Rate of snow-covered grassland & $\mathrm{X} 5\left(\mathrm{c}_{1}\right)$ & .551 & .135 & -.154 & -.293 & -.459 & -.515 & .047 \\
\hline Number of snow-covered days & $\mathrm{X} 6\left(\mathrm{c}_{2}\right)$ & .175 & .804 & .110 & .065 & -.141 & -.040 & -.015 \\
\hline Mean daily temperature below $0^{\circ} \mathrm{C}$ & $\mathrm{X} 7$ & .347 & .760 & .031 & -.126 & .211 & -.221 & -.027 \\
\hline Continual days of mean daily temperature below $-10^{\circ} \mathrm{C}$ & $\mathrm{X} 8$ (b) & .396 & .430 & -.014 & -.545 & .309 & .411 & .205 \\
\hline Grassland burial index & $\mathrm{X} 9\left(\mathrm{c}_{3}\right)$ & .518 & .068 & .075 & .167 & -.609 & .514 & .153 \\
\hline Livestock stocking rate & $\mathrm{X} 10$ & -.442 & .304 & -.604 & .127 & .053 & .162 & -.025 \\
\hline Herbage yield & $\mathrm{X} 2$ & .215 & -.552 & .545 & -.254 & .137 & -.037 & .219 \\
\hline Per capita GDP & $\mathrm{X} 1$ & .235 & .422 & .574 & .470 & .162 & .026 & -.247 \\
\hline Per livestock GDP & $\mathrm{X} 11(\mathrm{~d})$ & -.526 & .305 & .120 & .285 & .002 & -.165 & .705 \\
\hline Mean annual probability of snow disaster & X4 (a) & .786 & -.335 & -.195 & .375 & .114 & -.072 & .095 \\
\hline
\end{tabular}

Note: X1, X2 ,X3, X4, X5, X6, X7, X8, X9, X10, and X11 are used in the PC components; a, b, c $1, c_{2}, c_{3}$ and d are used in Eq. 1.

Table 6. Warning standard of snow disaster grades.

\begin{tabular}{lll}
\hline Snow disaster grade & $\begin{array}{l}\text { Death amount of } \\
\text { livestock }(\times 1000)\end{array}$ & Influence of snow on animal husbandry \\
\hline No disaster & 0 & $\begin{array}{l}\text { There is snow in the pastoral area, but the grassland burial index } \\
\text { is less than } 35 \% \text { or the rate of snow-covered grassland is less } \\
\text { than } 30 \% . \text { It has no obvious effect on the grazing. }\end{array}$ \\
\hline Light disaster & 50 & It has an effect on yak grazing, less on sheep, and none on horse. \\
\hline Moderate disaster & $50-100$ & It has an effect on yak and sheep grazing, and no effect on horse. \\
\hline Severe disaster & $100-200$ & $\begin{array}{l}\text { It has an effect on animal husbandry, and has greater losses for } \\
\text { yak and sheep. }\end{array}$ \\
\hline Extremely severe disaster & $>200$ & $\begin{array}{l}\text { It has an effect on all animal husbandry, and has the death of } \\
\text { livestock on a massive scale. }\end{array}$ \\
\hline
\end{tabular}

maps at $500 \mathrm{~m}$ spatial resolution. Figure 4 shows the workflow of the method using the grassland types, DEM, snow cover and depth datasets to calculate two parameters, grassland burial index (K) and number of snow-covered days (D), and then to determine the risk intensity at pixel scale. The potential risk intensities of snow disasters are divided into four levels: high risk, moderate risk, low risk and risk free (Table 7).

Figure 5 shows the potential grazing areas (and risk areas) derived solely based on grassland types and topographic slope $\left(\leq 50^{\circ}\right)$ (Wang and Cheng, 2002) criteria at $500 \mathrm{~m}$ grid cell. The map (Fig. 5) shows that the natural areas suitable for grazing under no snow conditions are mainly distributed in the southeastern area, with other smaller areas in the west, central, and northeast areas. Most areas in the northwest and north are potentially risk areas. Figures 6 and 7 are the two examples showing the simulated risk intensities with 4 levels of snow disasters for the periods $(\mathrm{J}=12,13)$ using real snow cover data for the periods of study.
Compared Fig. 6 with Fig. 2 and Fig. 7 with Fig. 3, it is clear that Figs. 6 and 7 show great detail of risk intensity distribution based on real snow condition for the period. Taking Bangoin County as an example, the risk warning result (Fig. 2) shows that the entire county could have incurred extremely severe snow disaster, while the simulated risk assessment map (Fig. 6) shows that the high or moderate risk areas could mostly occur in the central part and far-north part of the county, while the majority of the county was at low risk. Figure 7 shows that low-risk areas could remain in most of the TP. At the same time, the areas of high risk and moderate risk reduced, while the risk-free areas increased. This is also consistent with the risk warning map (Fig. 3) that shows Bangoin County downgraded from extremely severe disaster to severe disaster, while high-risk and moderate-risk areas in Amdo County remained the grade of extremely severe disaster, although it could have only occurred in the central part of the county (Figs. 7 and 6). It is interesting to see that Cona County in the very south of the TP was shown to have severe or moderate disasters in the simulation maps (Figs. 2 
Table 7. Lookup table for defining pixel-based risk intensity of snow disaster.

\begin{tabular}{cllll}
\hline \multirow{2}{*}{ Indicator and threshold } & \multicolumn{3}{c}{ Number of snow-covered (K) } \\
\cline { 2 - 5 } & & X6 $<10$ Days & 10 Days $\leq$ X6 $<20$ Days & X6 $\geq 20$ Days \\
\hline \multirow{3}{*}{ Grassland burial index (D) } & X $0<30 \%$ & Low risk & Low risk & Moderate risk \\
\cline { 2 - 5 } & $30 \% \leq X 9<60 \%$ & Low risk & Moderate risk & High risk \\
\cline { 2 - 5 } & $\mathrm{X} 9 \geq 60 \%$ & Moderate risk & High risk & High risk \\
\hline
\end{tabular}

Table 8. Accuracy assessment of the snow disaster warning model from 2008 to 2010 on the TP.

\begin{tabular}{|c|c|c|c|c|c|c|c|c|}
\hline \multirow[t]{2}{*}{ Year } & \multicolumn{2}{|c|}{ Agreement } & \multicolumn{2}{|c|}{ Disagreement } & \multirow{2}{*}{$\begin{array}{l}\text { False negatives } \\
(\%)\end{array}$} & \multirow{2}{*}{$\begin{array}{l}\text { False positives } \\
(\%)\end{array}$} & \multirow{2}{*}{$\begin{array}{l}\text { Snow disaster } \\
\text { accuracy }(\%)\end{array}$} & \multirow{2}{*}{$\begin{array}{l}\text { Overall } \\
\text { par accuracy } \\
(\%)\end{array}$} \\
\hline & Snow disaster & No disaster & $\begin{array}{l}\text { Only actual } \\
\text { records result }\end{array}$ & $\begin{array}{l}\text { Only } \\
\text { simulation } \\
\text { results }\end{array}$ & & & & \\
\hline 2008 & 169 & 58 & 19 & 18 & 10.11 & 23.68 & 89.89 & 85.98 \\
\hline 2009 & 35 & 62 & 0 & 21 & 0 & 25.30 & 100.00 & 82.20 \\
\hline 2010 & 19 & 9 & 1 & 0 & 5.00 & 0 & 95.00 & 96.55 \\
\hline Overall & 223 & 129 & 20 & 39 & 8.23 & 23.21 & 91.77 & 85.64 \\
\hline
\end{tabular}

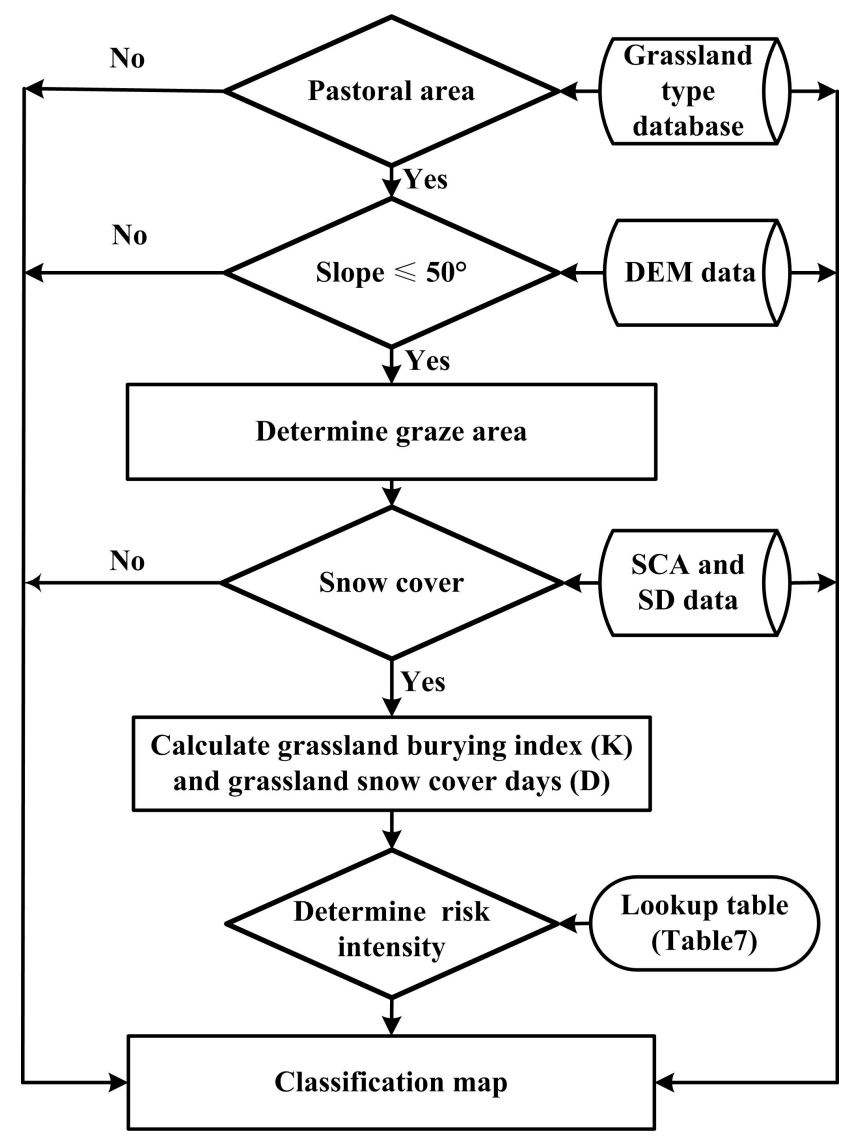

Fig. 4. Workflow for risk intensity classification of snow disasters.

$$
N_{\mathrm{a}}=\frac{S_{\mathrm{s}}}{S_{\mathrm{b}}+S_{\mathrm{s}}} \times 100
$$

and 3), while it is in the risk-free area of potential risk intensity maps (Figs. 5, 6, 7). This means that some parameters other than the topography, grassland type, and snow cover situations used in the risk assessment could cause snow disasters. Those parameters are integrated in the snow disasters model but not in the risk assessment approach (Fig. 4).

\section{Accuracy assessment of snow disaster warning model}

In order to avoid different measurement units of different indicators (e.g., per livestock GDP, livestock number, and snow disaster probability), we first conduct a normalization process, i.e., all independent variable values are divided by their corresponding maximum values. The independent variable values are then all within the range of $0-1$.

Using the above-normalized variables, the 411 chosen cases in the recent 3 yr (2008-2010) are applied to validate the early warning model of snow disasters, using the following four parameters: the overall accuracy $\left(O_{\mathrm{a}}\right)$, snow disaster accuracy $\left(S_{\mathrm{a}}\right)$, false negative accuracy $\left(N_{\mathrm{a}}\right)$ and false positive accuracy $\left(P_{\mathrm{a}}\right)$, as defined below.

$$
\begin{aligned}
O_{\mathrm{a}} & =\frac{S_{\mathrm{b}}+L_{\mathrm{b}}}{S_{\mathrm{b}}+S_{\mathrm{s}}+L_{\mathrm{b}}+L_{\mathrm{s}}} \times 100 \\
S_{\mathrm{a}} & =\frac{S_{\mathrm{b}}}{S_{\mathrm{b}}+S_{\mathrm{s}}} \times 100
\end{aligned}
$$




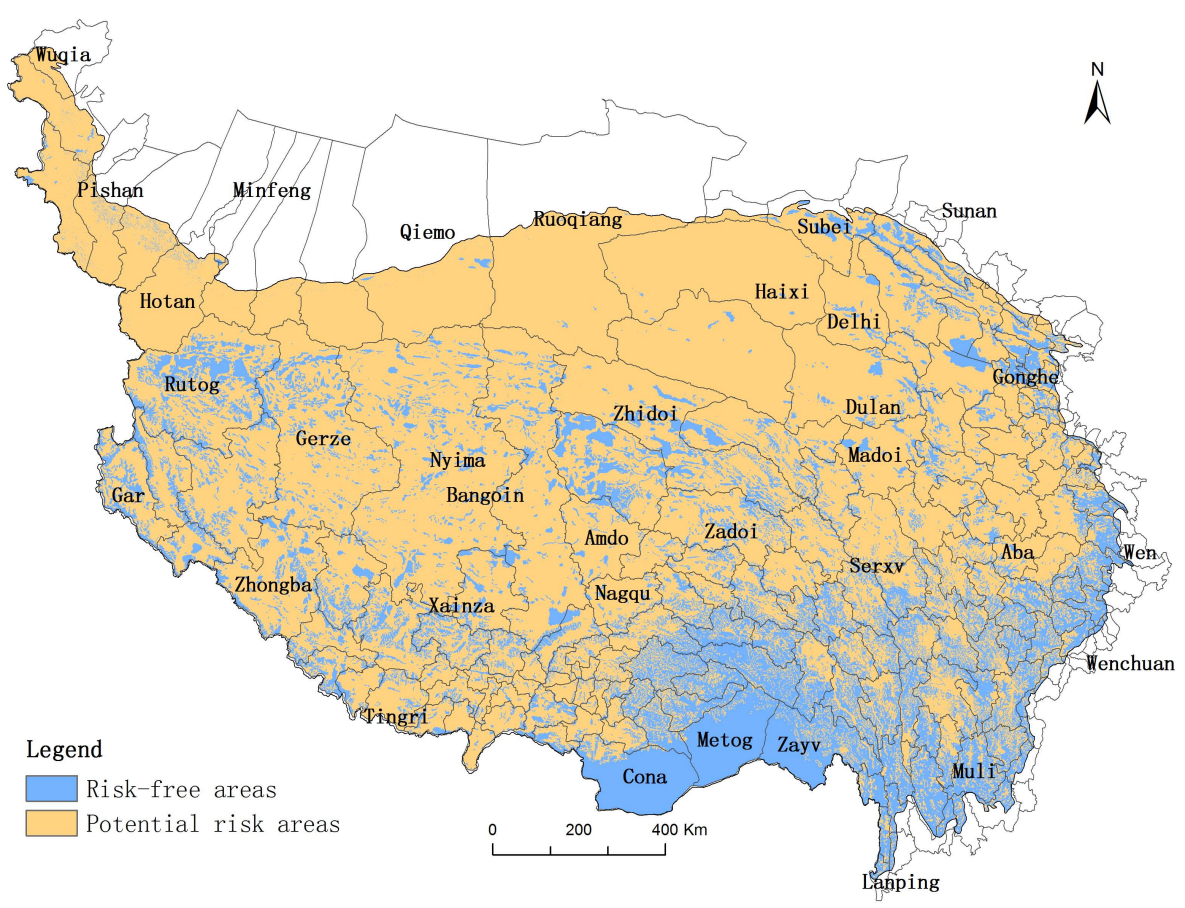

Fig. 5. Geographical distribution of potential risk-free and risk areas for livestock grazing at $500 \mathrm{~m}$ pixel scale under snow-free conditions.

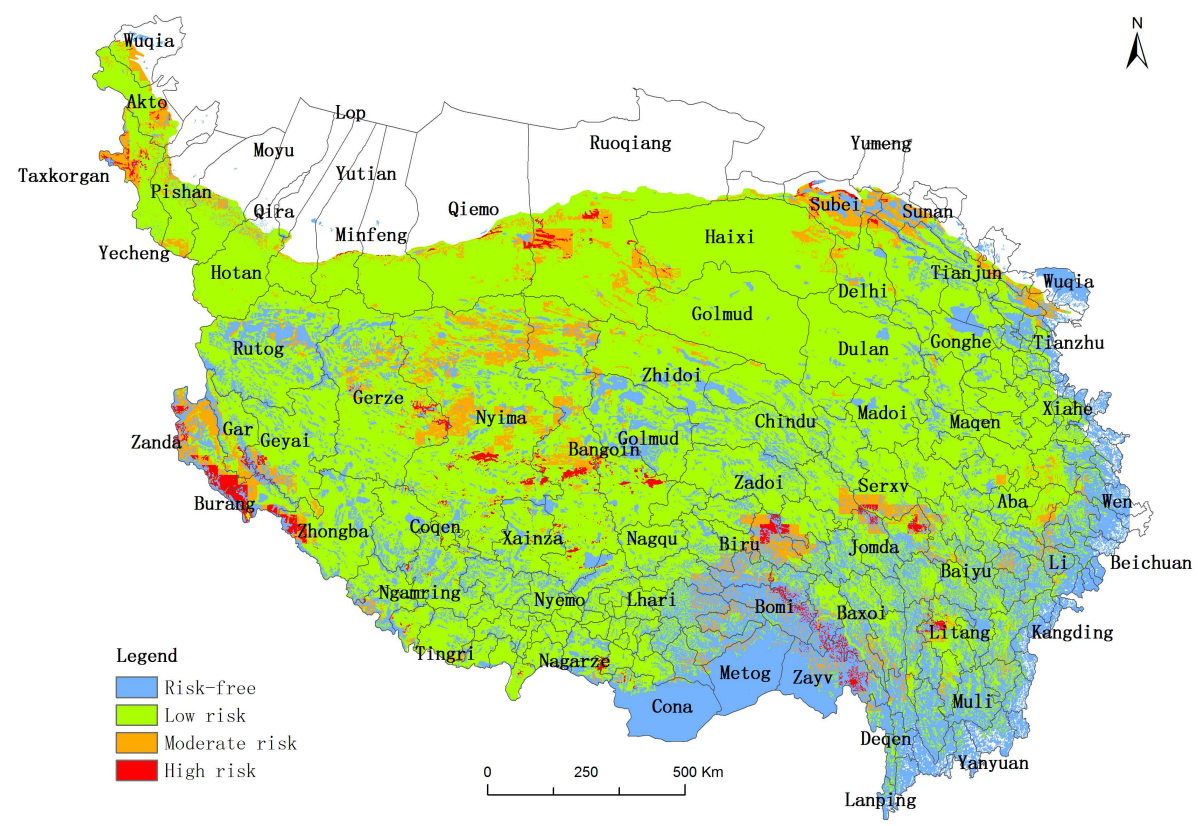

Fig. 6. Simulated risk intensity of snow disaster map at $500 \mathrm{~m}$ pixel scale in late January 2008 (J=12). 


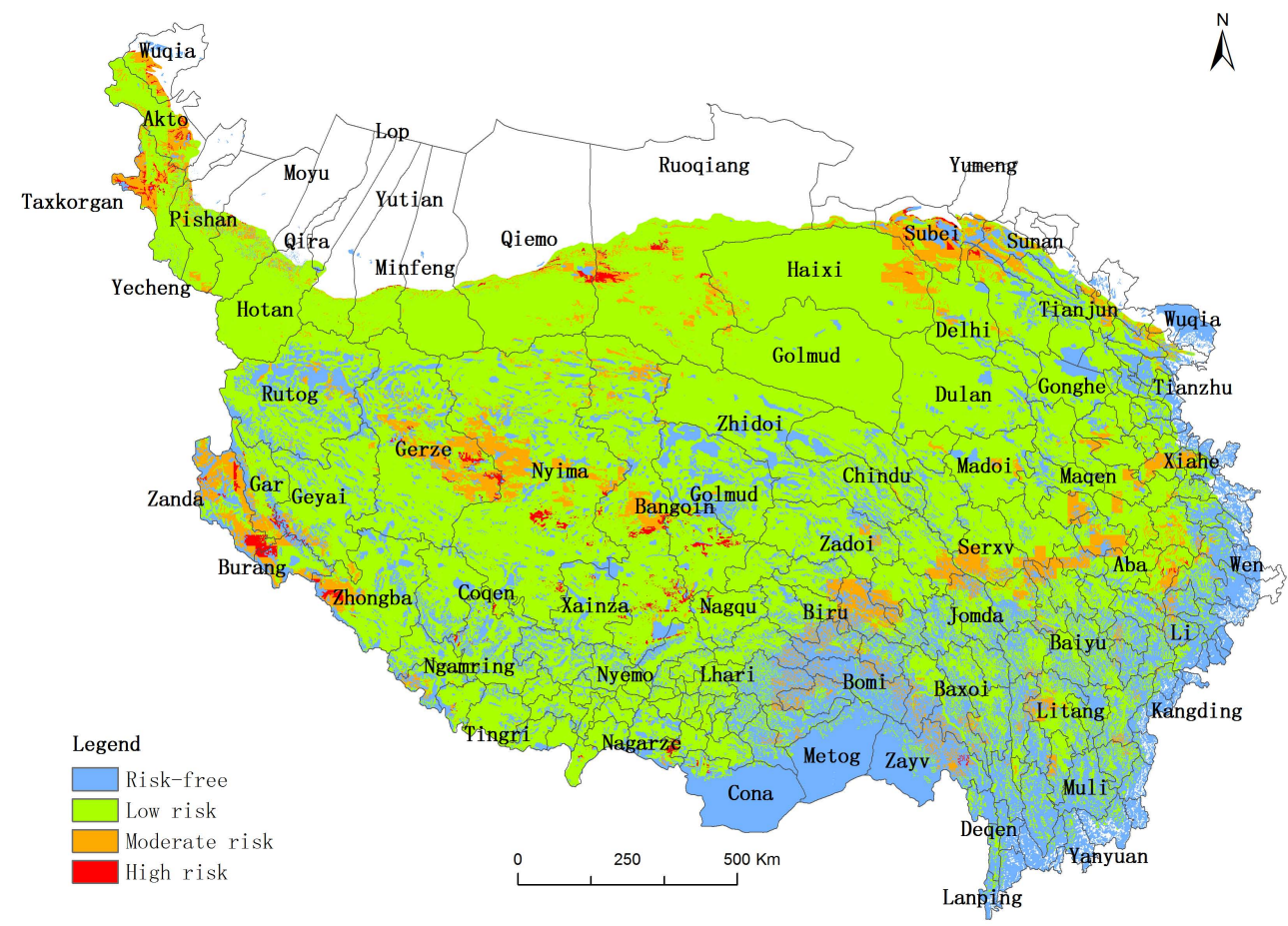

Fig. 7. Simulated intensity of snow disaster map at $500 \mathrm{~m}$ pixel scale in early February $2008(\mathrm{~J}=13)$

$P_{\mathrm{a}}=\frac{L_{\mathrm{s}}}{L_{\mathrm{b}}+L_{\mathrm{s}}} \times 100$

where $S_{\mathrm{b}}$ is the sampling number of snow disaster cases found by both statistical data and modeling results; $S_{\mathrm{s}}$ is the number of snow disaster cases found only by statistical data but misclassified into the grade no disaster by the model; $L_{\mathrm{b}}$ is the no-disaster number found by both statistical data and modeling results; and $L_{\mathrm{s}}$ is the no-disaster number found only by statistical data but misclassified as snow disaster by the model.

Since the validation cases do not have detailed numbers of livestock death, our validation can only show snow disaster or no disaster as indicated in Table 8 . The accuracies of overall, snow disasters, false negatives, and false positive are $82-97 \%, 89-100 \%, 0-10 \%$ and $0-25 \%$ for the examined $3 \mathrm{yr}$, respectively. The overall mean accuracy of the $3 \mathrm{yr}$ is $85.64 \%$.

\section{Discussion}

In this study, 201 counties on the TP are taken as a study area. MODIS and AMSR-E data, databases of grassland, snow cover, weather, livestock, society and economy, and typical snow disaster cases of recent $10 \mathrm{yr}$ (2001-2010) are used to develop methods of early warning of snow disasters. Results of the snow disaster cases show that occurrence of snow disasters was often not just the result of one heavy snowfall or temperature drop, but also affected by continuous snowfall and other factors, climatic indicators and snow cover condition being the main factors.

The TP is a very wide region. From Fig. 1 we can see that most of the ground meteorological stations used in the study are located in relatively populated and low-altitude areas (e.g., the northeastern part of the TP), while fewer stations are located in the central region where snow-caused disaster occurs frequently. This causes poor representation of continuous days of low temperature (i.e., below $-10^{\circ} \mathrm{C}$ ) in the snow disaster warning model. Meanwhile, all validation data came from meteorological data and report materials via Internet or journals. This clearly contributes to the modeling errors, due to the sparse distribution and poor representation of the meteorological stations, as well as the lacking of integrality from the report materials (i.e., no livestock loss data). Thus, it is hard to validate the disaster grades due to the limited cases with full and complete records. Although the combined MODIS and AMSR-E snow cover product is the best available, error caused by the coarse resolution of AMSR-E replacing the cloud-contaminated MODIS pixels (Gao et al., 2011) could transfer to the snow disaster model.

In the future, we need to strengthen the data collection methods and obtain more cases with accurate information about livestock losses and other related information, which can be used to validate the disaster grades predicted by our early warning model. 
The developed models for early warning of snow disasters and risk assessment are completely based on existing and available datasets, without considering any interference or assistance of human beings such as disaster relief by supplying a great amount of forage from other regions. However, it is well known that the degree and extent of snow disasters are not only related to the infrastructure (e.g., roads, communications and sheds for livestock) of disaster resistance and forage stock in a pastoral area, but also closely related to disaster rescue efforts.

Since the year 2000, the Chinese government has carried out the "Great Western Development" strategy in western China, which has greatly improved the existing grassland and animal husbandry production and management model. However, the traditional production and lifestyle formed over thousands of years for the local nomadic people in the region is hard to radically change in a short time. In the foreseeable future, the traditionally free-grazing style will certainly remain the major model of animal husbandry production on the TP. Therefore, the study carried out and the developed models of early warning and risk assessment will still play a significant role in snow disaster warning, relief, and prevention. To the best of our knowledge, it is the first time in the world such early warning and risk assessment models of snow disasters have been developed. Further efforts, however, particularly complete records of more cases of snow disasters, are needed to validate the prediction of disaster grades and to improve the models.

\section{Conclusions}

Early warning and risk assessment of snow disasters in pastoral areas play an important role in loss relief and sustainable development of regional grassland husbandry. This study develops a model for early warning of snow-caused livestock disasters on a county basis and proposes a method of qualitative risk assessment of snow disasters for pastoral areas on the TP. The results show that (1) there are 7 crucial factors that contribute to over $85 \%$ of information for early warning snow disasters on the TP. They are mean annual probability of snow disaster, snow-covered days, livestock stocking rate, continual days of mean daily temperature below $-10^{\circ} \mathrm{C}$, grassland burial index, rate of snow-covered grassland and per livestock GDP, of which per livestock GDP is a resistance disaster factor and others are disaster-causing factors. (2) Based on snow-caused disaster magnitude and snow influence on grazing of livestock, this study develops a model for early warning of snow disasters on a county basis and proposes a method of qualitative risk assessment of snow disasters at $500 \mathrm{~m}$ resolution for pastoral areas of the TP. The grades of snow disasters on a county basis are divided into no disaster, light disaster, moderate disaster, severe disaster, and extremely severe disaster. The risk intensities at $500 \mathrm{~m}$ scale are divided into four levels: no risk, low risk, moderate risk and high risk. And (3) we choose 411 cases from 2008 to 2010 to validate the prediction results from the developed early warning model. An overall mean accuracy of $85.64 \%$ is reached in classifying snow disaster and no disaster. This suggests that the early warning model generally can be used to predict snow disaster or no disaster, although we cannot validate the disaster grades due to limited information from the used 411 cases. However, accurately predicting snow disaster is already a great success for pastoral areas on the TP with harsh weather and high altitude that are difficult to reach for rescue and communication under heavy-snow conditions. Therefore, our early warning model of snow disasters has a potential for operational use.

Acknowledgements. The authors are grateful to the editors and two anonymous reviewers for their valuable and constructive suggestions which have greatly aided in improving the presentation of this manuscript. This work was supported by the Cultivation Fund of the Key Scientific and Technical Innovation Project, Ministry of Education of China (\#708089), the Chinese Natural Science Foundation Projects (\#41101337, \#31228021, and \#41071342), and the Fundamental Research Funds for the Central University (lzujbky-2013-103).

Edited by: N. Casagli

Reviewed by: S. Segoni and two anonymous referees

\section{References}

Blöschl, G., Kirnbauer, R., and Gutknecht, D.: Distributed snowmelt simulations in an Alpine catchment, 1. Model evaluation on the basis of snow cover patterns, Water Resour. Res., 27, 3171-3179, 1991.

Bocchiola, D., Bianchi Janetti, E., Gorni, E., Marty, C., and Sovilla, B.: Regional evaluation of three day snow depth for avalanche hazard mapping in Switzerland, Nat. Hazards Earth Syst. Sci., 8, 685-705, doi:10.5194/nhess-8-685-2008, 2008.

Chang, A. T. C., Foster, J. L., and Hall, D. K.: Effects of forest on the snow parameters derived from microwave measurements during the boreas winter field campaign, Hydrol. Process., 10, 1565-1574, 1996.

Che, T. and Li, X.: Retrieval of Snow Depth in China by Passive Microwave Remote Sensing Data and Its Accuracy Assessment, Remote. Sens. Technol. Appl., 19, 301-305, 2004 (in Chinese).

Che, T., Dai, L. Y., Wang, J., Zhao, K., and Liu, D.: Estimation of snow depth and snow water equivalent distribution using airborne microwave radiometry in the Binggou Watershed, the upper reaches of the Heihe River basin, Int. J. Appl. Earth Obs., 17, 23-32, 2012.

China Meteorological Administration: China Meteorological Yearbook 2010, China Meteorological Press, Beijing, 105-173, 2011 (in Chinese).

Dai, L. Y., Che, T., Wang, J., and Zhang, P.: Snow depth and snow water equivalent estimation from AMSR-E data based on a priori snow characteristics in Xinjiang, China, Remote. Sens. Environ., 127, 14-29, 2012. 
Delparte, D., Jamieson, B., and Waters, N.: Statistical runout modeling of snow avalanches using gis in glacier national park, canada, Cold Reg. Sci. Technol., 54, 183-192, 2008.

Feng, Q., Gao, X., Huang, X., Yu, H., and Liang, T.: Remote sensing dynamic monitoring of grass growth in qinghai-tibet plateau from 2001 to 2010, J. Lanzhou U., 47, 75-90, 2011 (in Chinese).

Foster, J. L., Chang, A. T. C., and Hall, D. K.: Comparison of Snow Mass Estimates from a Prototype Passive Microwave Snow Algorithm, A Revised Algorithm and a Snow Depth Climatology, Remote. Sens. Environ., 62, 132-142, 1997.

Freedman, D., Pisani, R., and Purves, R.: Statistics. Norton \& Company, New York, 44-103, 1998.

Frei, A., Tedesco, M., Lee, S., Foster, J., Hall, D. K., Kelly, R., and Robinson, D.A.: A review of global satellite-derived snow products, Adv. Space Res., 50, 1007-1029, 2012.

Gao, Y., Xie, H., Lu, N., Yao, T., and Liang, T.: Toward advanced daily cloud-free snow cover and snow water equivalent products from terra-aqua modis and aqua amsr-e measurements, J. Hydrol., 385, 23-35, 2010.

Gao, Y., Xie, H., and Yao, T.: Developing snow cover parameters maps from MODIS, AMSR-E and blended snow products, Photogramm. Eng. Rem. S., 77, 351-361, 2011.

General Administration of Quality Supervision of China: Inspection and Quarantine of the People's Republic of China, Standarization Administration of the People's Republic of China.: Chinese national standard, in: Grade of pastoral area snow disaste, China Standards Press, Beijing, 1-7, 2006 (in Chinese).

Gutzler, D. S. and Rosen, R. D.: Interannual variability of wintertime snow cover across the northern hemisphere, J. Climate, 5, 1441-1448, 1992.

Hall, D. K., Foster, J. L., Salomonson, V. V., Klein, A. G., and Chien, J. Y. L.: Development of a technique to assess snow-cover mapping errors from space, IEEE T. Geosci Remote., 39, 432438, 2001

Hall, D. K., Riggs, G. A., Salomonson, V. V., DiGirolamob, S. N., and Bayr, K. J.: MODIS snow-cover products, Remote. Sens. Environ., 83, 181-194, 2002.

Hendrikx, J., Owens, I., Carran, W., and Carran, A.: Avalanche activity in an extreme maritime climate: The application of classification trees for forecasting, Cold Reg. Sci. Technol., 43, 104116, 2005.

Hirashima, H., Nishimura, K., Yamaguchi, S., Sato, A., and Lehning, M.: Avalanche forecasting in a heavy snowfall area using the snowpack model, Cold Reg. Sci. Technol., 51, 191-203, 2008.

Jones, A. S. T. and Jamieson, B.: Meteorological forecasting variables associated with skier-triggered dry slab avalanches, Cold Reg. Sci. Technol., 33, 223-236, 2001.

Lato, M. J., Frauenfelder, R., and Bühler, Y.: Automated detection of snow avalanche deposits: segmentation and classification of optical remote sensing imagery, Nat. Hazards Earth Syst. Sci., 12, 2893-2906, doi:10.5194/nhess-12-2893-2012, 2012.

Lemke, P., Ren, J., Alley, R. B., Allison, I., Carrasco, J., and Flato, G.: Observations: Changes in snow, ice and frozen ground, Climate Change, 337-383, 2007.

Liang, T. G., Liu, X. Y.,Wu, C. X., Guo, Z. G., and Huang, X. D.: An evaluation approach for snow disasters in the pastoral areas of Northern Xinjiang, PR China, New. Zeal. J. Agr. Res., 50, 369 380, 2007.
Liang, T., Zhang, X., Xie, H., Wu, C., Feng, Q., Huang, X., and Chen, Q.: Toward improved daily snow cover mapping with advanced combination of modis and amsr-e measurements, Remote. Sens. Environ., 112, 3750-3761, 2008a.

Liang, T. G., Huang, X. D., Wu, C. X., Liu, X. Y., Li, W. L., Guo, Z. G., and Ren, J. Z.: An application of modis data to snow cover monitoring in a pastoral area: A case study in northern xinjiang, china, Remote. Sens. Environ., 112, 1514-1526, 2008 b.

Liu, G.: Meteorological disaster yearbook of china, China Meteorological Press, Beijing, 256, 2008a (in Chinese).

Liu, J.: Meteorological disaster yearbook of china, China Meteorological Press, beijing, 540, 2008b (in Chinese).

Liu, X., Liang, T., Guo, Z., and Zhang, X.: Early warning and risk assessment of snow disaster in pastoral area of northern xinjiang, Chinese J. Appl. Ecol., 19, 133-138, 2008 (in Chinese).

Lu, A., Feng, X., Zeng, Q., and Wang, L.: Principal component analysis of the snow disaster factors in the pastoral nagqu prefecture, tibet region, J. Glaciol. Geocryol., 19, 86-91, 1997 (in Chinese).

Martelloni, G., Segoni, S., Lagomarsino, D., Fanti, R., and Catani, F.: Snow accumulation/melting model (SAMM) for integrated use in regional scale landslide early warning systems, Hydrol. Earth Syst. Sci., 17, 1229-1240, doi:10.5194/hess-17-12292013, 2013.

Mercogliano, P., Segoni, S., Rossi, G., Sikorsky, B., Tofani, V., Schiano, P., Catani, F., and Casagli, N.: Brief communication "A prototype forecasting chain for rainfall induced shallow landslides", Nat. Hazards Earth Syst. Sci., 13, 771-777, doi:10.5194/nhess-13-771-2013, 2013.

Ministry of Agriculture of the People's Republic of China, Animal Husbandry Department: China grassland resources, China science and technology press, Beijing, 678, 1986 (in Chinese).

Nagelkerke, N. J. D.: A note on a general definition of the coefficient of determination. Biometrika, 78, 691-692, 1991.

Nakai, S., Sato, T., Sato, A., Hirashima, H., Nemoto, M., Motoyoshi, H., Iwamoto, K., Misumi, R., Kamiishi, I., Kobayashi, T., Kosugi, K., Yamaguchi, S., Abe, O., and Ishizaka, M.: A Snow Disaster Forecasting System (SDFS) constructed from field observations and laboratory experiments, Cold Reg. Sci. Technol., 70, 53-61, 2012.

Nakamura, M. and Shindo, N.: Effects of snow cover on the social and foraging behavior of the great tit parus major, Ecol. Res., 16, 301-308, 2001.

Paudel, K. P. and Andersen, P.: Monitoring snow cover variability in an agropastoral area in the Trans Himalayan region of Nepal using MODIS data with improved cloud removal methodology, Remote. Sens. Environ., 115, 1234-1246, 2011.

Pulliainen, J.: Mapping of snow water equivalent and snow depth in boreal and sub-arctic zones by assimilating space-borne microwave radiometer data and ground-based observations, Remote. Sens. Environ., 101, 257-269, 2006.

Robock, A.: The seasonal cycle of snow cover, sea ice and surface albedo, Mon. Weather Rev., 108, 267-285, 1980.

Rodell, M. and Houser, P. R.: Updating a land surface model with MODIS derived snow cover, J. Hydrometeorol., 5, 1064-1075, 2004.

Romanov, P., Gutman, G., and Csiszar, I.: Satellite-derived snow cover maps for north america: Accuracy assessment, Adv. Space Res., 30, 2455-2460, 2002. 
Rossi, G., Catani, F., Leoni, L., Segoni, S., and Tofani, V.: HIRESSS: a physically based slope stability simulator for HPC applications, Nat. Hazards Earth Syst. Sci., 13, 151-166, doi:10.5194/nhess-13-151-2013, 2013.

Shi, Y.: Meteorological disaster yearbook of china, China Meteorological Press, Beijing, 340, 2008 (in Chinese).

Stowe, L. L., McClain, E. P., Carey, R., Pellegrino, P., Gutman, G. G., Davis, P., Long, C., and Hart, S.: Global distribution of cloud cover derived from noaa/avhrr operational satellite data, Adv. Space Res., 11, 51-54, 1991.

Tachiiri, K., Shinoda, M., Klinkenberg, B., and Morinaga, Y.: Assessing mongolian snow disaster risk using livestock and satellite data, J. Arid Environ., 72, 2251-2263, 2008.

Tominaga, Y., Mochida, A., Okaze, T., Sato, T., Nemoto, M., Motoyoshi, H., Nakai, S., Tsutsumi, T., Otsuki, M., Uamatsu, T., and Yoshino, H.: Development of a system for predicting snow distribution in built-up environments: Combining a mesoscale meteorological model and a cfd model, J. Wind Eng. Ind. Aerod., 99, 460-468, 2011.

Wang, S.: Meteorological disaster yearbook of china, China Meteorological Press, Beijing, 417, 2008 (in Chinese).

Wang, D. and Cheng, Z.: Theoretical study of the feeding behavior of grazing livestock, Prog. Mod. Grassland, 132-134, 2002 (in Chinese).
Wang, X. and Xie, H.: New methods for studying the spatiotemporal variation of snow cover based on combination products of modis terra and aqua, J. Hydrol., 371, 192-200, 2009.

Wen, K.: Meteorological disaster yearbook of china, China Meteorological Press, Beijing, 448, 2008 (in Chinese).

Williamson, R. A., Hertzfeld, H. R., Cordes, J., and Logsdon, J. M.: The socioeconomic benefits of earth science and applications research: Reducing the risks and costs of natural disasters in the USA, Space Policy, 18, 57-65, 2002.

Yu, H., Zhang, X., Liang, T., Xie, H., Wang, X., Feng, Q., and Chen, Q.: A new approach of dynamic monitoring of 5-day snow cover extent and snow depth based on MODIS and AMSR-E data from Northern Xinjiang region, Hydrol. Process., 26, 30523061, 2012.

Zhan, Z.: Meteorological disaster yearbook of china, China Meteorological Press, Beijing, 602, 2008 (in Chinese).

Zhang, G., Fu, Y., Yan, L., Liu, B., Shi, D., and Yang, L.: Study on warning indicator system of snow disaster and risk management in headwaters region, Pratacultural Science, 26, 144-150, 2008 (in Chinese).

Zhang, Y., Li, B., and Zhang, D.: A discussion on the boundary and area of the tibetan plateau in china, Geogr. Res., 21, 1-8, 2002 (in Chinese).

Zhou, B., Shen, S., and Li, F.: A synthetical forcasting model of snow disaster in qinghai-tibet plateau, Meteorological, 32, 106110, 2006 (in Chinese). 